\title{
Scorpions, snakes, and Fontan failure: The dawn of a new ERA?
}

\author{
Edward Buratto, MBBS, ${ }^{a}$ Xin Tao Ye, MD, ${ }^{b}$ and Igor E. Konstantinov, MD, PhD, FRACS
}

\footnotetext{
From the ${ }^{\mathrm{a}}$ Department of Cardiac Surgery, The Royal Children's Hospital; ${ }^{\mathrm{b}}$ Department of Paediatrics, The University of Melbourne; and ${ }^{\mathrm{c}}$ Murdoch Children's Research Institute, Melbourne, Australia.

Disclosures: Authors have nothing to disclose with regard to commercial support.

Received for publication Feb 27, 2017; accepted for publication March 2, 2017; available ahead of print March 31, 2017.

Address for reprints: Igor E. Konstantinov, MD, PhD, FRACS, Royal Children's Hospital, Flemington Rd, Parkville, VIC 3029, Australia (E-mail: igor.konstantinov@rch.org.au).

J Thorac Cardiovasc Surg 2017;153:1476-8

$0022-5223 / \$ 36.00$

Crown Copyright (c) 2017 Published by Elsevier Inc. on behalf of The American Association for Thoracic Surgery http://dx.doi.org/10.1016/j.jtcvs.2017.03.008
}

It never ceases to amaze us how often the most fascinating mysteries of evolution intertwine with our routine surgical practice in subtle and unexpected ways. Relentless work of evolution over millions of years has resulted in venom peptides that rapidly incapacitate both prey and predators. The most dangerous scorpions and snakes have evolved to produce highly potent venom that induces severe coronary vasoconstriction and almost immediate ventricular fibrillation. It is remarkable that the most toxic component of this venom, sarafotoxin, is structurally very similar to another 21-residue peptide-endothelin (ET) - a natural compound of the human vascular system.

The family of ETs consists of 4 peptides that are converted from a common precursor, preproendothelin, by ET-converting enzyme in endothelial cells (Figure 1). The major isoform in the human vascular system is ET-1. ET-1 causes vasoconstriction and cell proliferation via activation of $\mathrm{ET}_{\mathrm{A}}$ and $\mathrm{ET}_{\mathrm{B}}$ receptors on vascular smooth muscle cells. ${ }^{2}$ Stimulation of endothelial $\mathrm{ET}_{\mathrm{B}}$ receptors causes vasodilatation via nitric oxide and prostacyclin pathways. ${ }^{3}$ Furthermore, $\mathrm{ET}_{\mathrm{B}}$ receptors in the pulmonary endothelium are a major route for the clearance of ET-1. ${ }^{4}$ In patients with congestive heart failure, increased ET-1 level correlates with adverse outcomes. The main source of ET-1 in congestive heart failure appears to be the pulmonary vascular bed and it contributes significantly to increased pulmonary vascular resistance. ${ }^{5}$ Negating ET1-induced pulmonary vasoconstriction would be of utmost importance in patients with failing Fontan circulation, particularly, because the majority of these patients have preserved systolic ventricular function, yet elevated pulmonary vascular resistance and impaired ventricular relaxation. ${ }^{6}$ Elevated pulmonary vascular resistance in patients with failing Fontan circulation is, at least in part, due to decreased nitric oxide production and elevated plasma ET levels. ${ }^{7,8}$ Current medical management of patients with Fontan failure is extremely limited and, at its very best, may somewhat delay a steady decline in functional

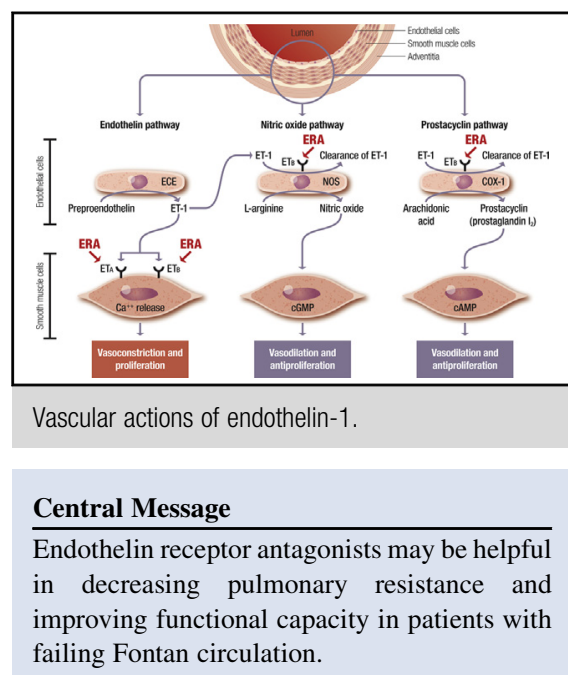

See Article page 1468.

capacity of patients with a failing Fontan circulation. The current mainstay of treatment for patients with Fontan failure is cardiac transplantation, yet transplantation is challenging in these patients and, due to its complexity, limited donor supply, and substantial waiting list mortality, may not be readily available to most patients. ${ }^{9}$ Thus far, only a few small studies have examined the effects of pulmonary vasodilators on patients with a Fontan circulation. Two small, randomized trials have shown that that sildenafil could improve cardiac index, pulmonary blood flow, oxygen consumption, and ventilatory efficiency in patients with a Fontan circulation who underwent cardiopulmonary exercise testing. ${ }^{10,11}$ Results for endothelin receptor antagonists (ERAs) have been equivocal, with 2 small randomized trials showing improvement exercise capacity, oxygen consumption, and functional class, ${ }^{1,12}$ whereas a third trial showed no benefit. $^{13}$

A very interesting article by Agnoletti and colleagues ${ }^{14}$ describes the effects of ERAs in patients with raised pulmonary vascular resistance and a Fontan circulation. In this small, nonrandomized trial they treated 24 patients with 2 different types of ERAs (bosentan for children, including adolescents, and macitentan for adults). They demonstrated that over a 6-month period, the use of ERAs was associated with a decrease in pulmonary resistance, improvement in cardiac output, and spirometric parameters. Furthermore, cardiopulmonary exercise testing 


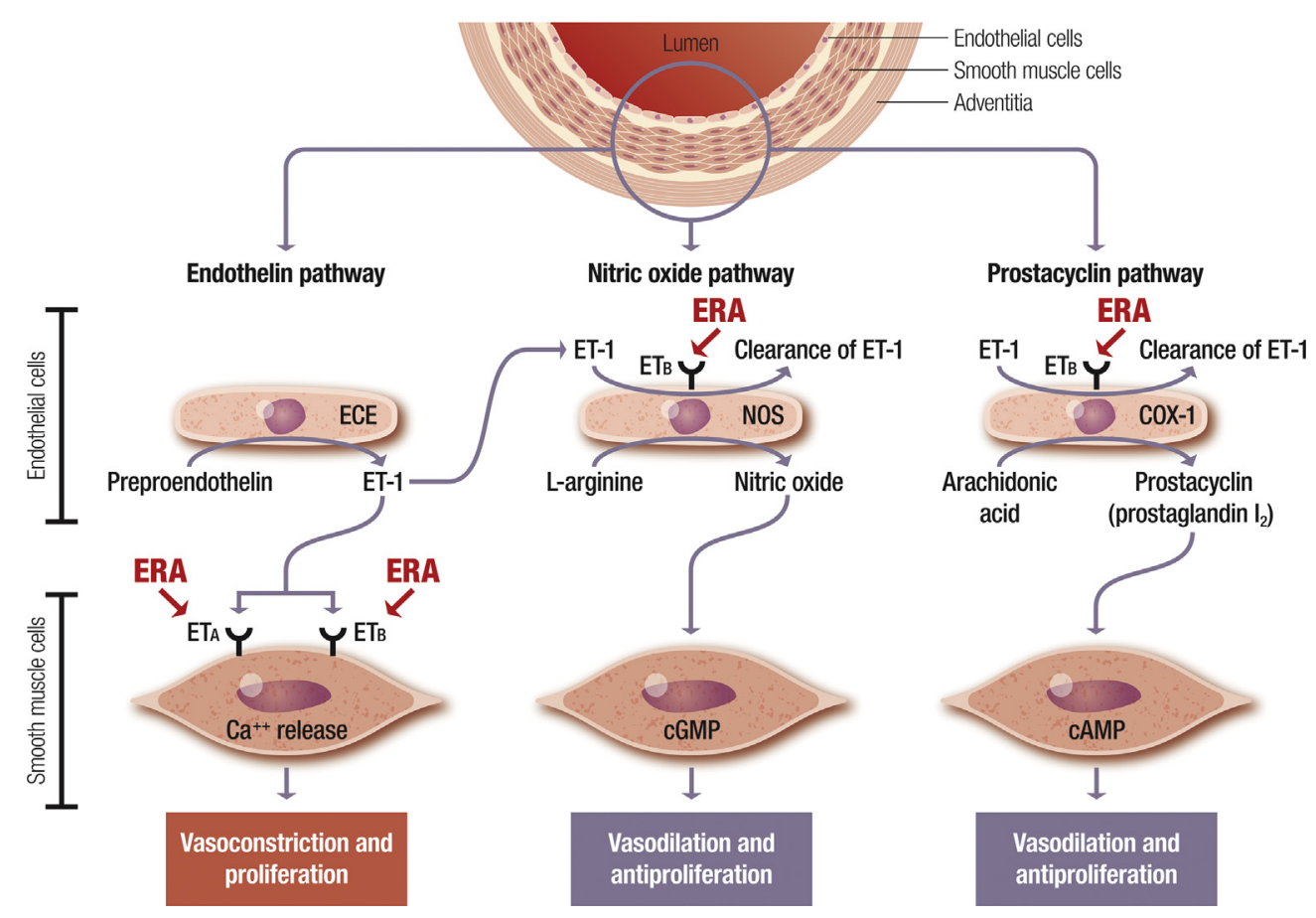

FIGURE 1. Vascular actions of endothelin-1. ECE, Endothelin converting enzyme; $E R A$, endothelin receptor antagonist; $E T$, endothelin; NOS, nitric oxide synthetase; $C O X$, cyclo-oxygenase; $c G M P$, cyclic guanylyl triphosphate; $c A M P$, cyclic adenylyl monophosphate.

showed improvement in both younger children and adolescents, but not in adults.

There are several key findings in this study. This is the first demonstration that ERAs do not only decrease pulmonary vascular resistance, but also improve hemodynamic and respiratory parameters in patients with a Fontan circulation. Furthermore, they observed that functional improvement was essentially limited to children and adolescents, although significant decrease in pulmonary vascular resistance occurred in all patients. This could be because of a more advanced and often multifactorial circulatory failure in adult patients with long-standing failure of Fontan circulation. This may also explain why some trials, which enrolled older patients, have shown no benefits of ERAs in patients with Fontan failure. Alternatively, because adults received macitentan, whereas minors received bosentan, this may reflect the differential efficacy of drugs within the ERA class. It should be remembered that although both are dual ERAs, macitentan has a 50-fold increased selectivity for the $\mathrm{ET}_{\mathrm{A}}$ subtype compared with the $\mathrm{ET}_{\mathrm{B}}$ subtype. ${ }^{15}$ Because there are higher numbers of $\mathrm{ET}_{\mathrm{A}}$ receptors than $\mathrm{ET}_{\mathrm{B}}$ receptors in smooth muscle cells of the pulmonary arteries, blocking the $\mathrm{ET}_{\mathrm{A}}$ receptors would appear more important in the treatment of pulmonary hypertension. ${ }^{16}$ Furthermore, macitentan has a high receptor occupancy half-life (17 minutes) compared with that of bosentan (70 seconds), and this essentially makes macitentan act as a noncompetitive antagonist of ET receptors, whereas bosentan remains a completive antagonist. ${ }^{16}$ At least in theory, macitentan would block the vasoconstriction effect of $\mathrm{ET}_{\mathrm{A}}$ receptors and yet preserve, to some extent, vasodilation and clearance effects of $\mathrm{ET}_{\mathrm{B}}$ receptors. Why then was macitentan not effective in improving functional capacity in adults? Provided that there were no issues with sample size, the more advanced multifactorial failure of Fontan circulation would be a logical explanation. It should also be said that although $\mathrm{ET}_{\mathrm{B}}$ receptors mediate vasodilatation in healthy individuals, $\mathrm{ET}_{\mathrm{B}}$ receptors may cause vasoconstriction in patients with heart failure. ${ }^{17}$

Although the true influence of ERA on management in patients with failing Fontan circulation remains unclear, the study by Agnolletti and colleagues ${ }^{14}$ is an important step forward because it is the first study to clearly demonstrate beneficial effects of ERA in Fontan patients with increased pulmonary resistance. One can only hope that such profound effects on pulmonary resistance will be confirmed in randomized controlled trials and will result in long-term benefits. The path of least resistance may truly prove to be the path of the winner!

\section{References}

1. Klooq Y, Ambar I, Sokolovsky M, Kochva E, Wollberg Z, Bdolah A. Sarafotoxin, a novel vasoconstrictor peptide: phosphoinosite hydrolysis in rat heart and brain. Science. 1988;242:268-70.

2. Spieker LE, Noll G, Ruschitzka FT, Luscher TF. Endothelin receptor antagonists in congestive heart failure: a new therapeutic principle for the future? J Am Coll Cardiol. 2001;37:1493-505.

3. Verhaar MC, Strachan FE, Newby DE, Cruden NL, Kooman HA, Rabelink TJ, et al. Endothelin-A receptor antagonist-mediated vasodilatation is attenuated by inhibition of nitric oxide synthesis and by endothelin-B receptor blockade. Circulation. 1998;97:752-6. 
4. Dupius J, Stewart DJ, Cernacel P, Gosselin G. Human pulmonary circulation is an important site for both clearance and production of endothelin-1. Circulation. 1996;94:1578-84.

5. Tsutamoto T, Wada A, Maeda Y, Adachi T, Kinoshita M. Relation between endothelin-1 spillover in the lungs and pulmonary vascular resistance in patients with chronic heart failure. J Am Coll Cardiol. 1994;23:1427-33.

6. Jaquiss RD, Aziz H. Is four stage management the future of univentricular hearts? Destination therapy in the young. Semin Thorac Cardiovasc Surg Pediatr Card Surg Annu. 2016;19:50-4.

7. Henaine R, Vergnat M, Bacha EA, Baudet B, Lambert V, Belli E, et al. Effects of lack of pulsatility on pulmonary endothelial function in the Fontan circulation. $J$ Thorac Cardiovasc Surg. 2013;146:522-9.

8. Yamagishi M, Kurosawa H, Hashimoto K, Nomura K, Kitamura N. The role of plasma endothelin in the Fontan circulation. J Cardiovasc Surg (Torino). 2002; 43:793-7.

9. Shi WY, Yong MS, McGiffin DC, Jain P, Ruygrok PN, Marasco SF, et al. Heart transplantation in Fontan patients across Australia and New Zealand. Heart. 2016;102:1120-6.

10. Goldberg DJ, French B, McBride MG, Marino BS, Mirarchi N, Hanna BD, et al. Impact of oral sildenafil on exercise performance in children and young adults after the Fontan operation: a randomized, double-blind, placebo-controlled, crossover trial. Circulation. 2011;123:1185-93.

11. Hebert A, Mikkelsen UR, Thilen U, Idorn L, Jensen AS, Nagy E, et al. Bosentan improves exercise capacity in adolescents and adults after Fontan operation: the
TEMPO (Treatment With Endothelin Receptor Antagonist in Fontan Patients, a Randomized, Placebo-Controlled, Double-Blind Study Measuring Peak Oxygen Consumption) study. Circulation. 2014;130:2021-30.

12. Cedars AM, Saef J, Peterson LR, Coggan AR, Novak EL, Kemp D, et al. Effect of ambrisentan on exercise capacity in adult patients after the Fontan procedure. Am J Cardiol. 2016;117:1524-32.

13. Schuuring MJ, Vis JC, van Dijk AP, van Melle JP, Vliegen HW, Pieper PG, et al. Impact of bosentan on exercise capacity in adults after the Fontan procedure: a randomized controlled trial. Eur J Heart Fail. 2013;15:690-8.

14. Agnoletti G, Gala S, Ferroni F, Bordese R, Appendini L, Napoleone CP, et al. Endothelin inhibitors lower pulmonary vascular resistances and improve functional capacity in patients with Fontan Circulation. J Thorac Cardiovasc Surg. 2017; $153: 1468-75$

15. Iglarz M, Binkert C, Morrison K, Fischli W, Gatfield J, Treiber A, et al. Pharmacology of macitentan, an orally active tissue-targeting dual endothelin receptor antagonist. J Pharmacol Exper Therapeutics. 2008;327:736-45.

16. Gatfield J, Grandjean CM, Sasse T, Clozel M, Nayler O. Slow receptor dissociation kinetics differentiate macitentan from other endothelin receptor antagonists in pulmonary arterial smooth muscle cells. PLOS ONE. 2012;7: e47662.

17. Cowburn PJ, Cleland JG, McArthur JD, MacLean MR, McMurray JJ, Dargie HJ, et al. Endothelin-B receptors are functionally important in mediating vasoconstriction in systemic circulation in patients with left ventricular systolic dysfunction. J Am Coll Cardiol. 1999;33:932-8. 